\title{
sciendo
}

DOI 10.2478/sbe-2019-0049

SBE no. 14(3) 2019

\section{THE EFFECT OF CREDIT COLLECTION POLICY ON PORTFOLIO AT RISK OF MICROFINANCE INSTITUTIONS IN TANZANIA}

\author{
NGONYANI DANSTUN \\ St John's University of Tanzania, Tanzania \\ MAPESA HARUN \\ School of Business, Mzumbe University, Tanzania
}

\begin{abstract}
:
This paper presents the results of the study on the effect of credit collection policy on portfolio at risk of microfinance institutions in Tanzania. The study used cross-sectional survey data of microfinance institutions in three regions of Dar es salaam, Morogoro and Dodoma. Random sampling was employed to obtain a sample of 219 respondents in all three regions. Multiple linear regression analysis was used to determine the effect of credit collection policy on portfolio at risk of microfinance institutions. Results show that, there is a positive relationship between interest rates charged and portfolio at risk of microfinance institutions. On the other hand, the variable for grace period on loans and loan sizes to borrowers had a negative relationship with portfolio at risk of microfinance institutions. The study recommends that, microfinance institutions in Tanzania need to reconsider the interest rates charged to their clients to enhance sustainability of their loan portfolios. Moreover, microfinance institutions need to enhance provision of grace period to their customers. Also, establish efficient loan product sizes which suffice diverse client's needs. That would encourage and broaden client repayments, contribute to financial performance and reduced risk of portfolio of microfinance institutions.
\end{abstract}

Key words: Credit collection, Portfolio at risk, Microfinance institutions

\section{Introduction}

Microfinance institutions are proven to have significant contribution in reducing poverty among the low-income earners and disadvantaged individuals in society. These institutions have been helpful in facilitating entrepreneurship skills and provision of knowledge on capital, risks and empowerment in economic activities (Colquitt, 2007). Microfinance institutions intended to simplify provision of micro financial services to low 
income households and self-employed individuals (Brown and Moles, 2011). In order to continue serving their clients with microcredit facilities. The lending institutes need to effectively manage their loan portfolios. Microfinance portfolio management is the driving force to enable sustainable financial performance. Microfinance institutions that experience high risk of its loan portfolio, is an indication of high delinquency from customers. This may lead to underperformance of its loan portfolio thus threatening the ability to continue in operation in the long-term (Ledgerwood, 1999). Microfinance institution need to manage portfolio quality against delinquency and defaults, by establishing effective strategies in the lending and collection processes. Efficient credit collection policy within the institutional framework, helps credit management process be effective and hence timely collection of funds from clients.

However, there have been controversy from the microfinance institutions concerning high rate of default/delinquency by their clients. Increase of default rates in loan portfolios indicates that microfinance institutions are not attaining the internationally accepted standard portfolio at risk of 3\%. In addition, MIX (2010) reported that MFIs in Sub Saharan Africa had increased portfolio at risk with region records greater than $5 \%$. This is a cause of concern since it erodes effort put forth of establishing microfinance institution and ensure financial inclusion of poor people. Schmittlen, (2010); Colquitt, (2007) pointed out that, weak credit collection policy has been the main cause of business failures including microfinance institutions. The essence of microfinance credit collection policy is to facilitate effective credit administration of disbursed funds. Also, ensure that microfinance institutions rate of returns outweigh the cost incurred to delivering credit. Existence of efficient credit collection policy within institutional framework, helps loan officers be effective and timely in collection of funds from clients. Emphasis need to be put in appraising and credit supervision of borrowers. Microfinance institution that invests into borrowers' ability to self-response to loan repayment have a better chance to maintain quality loan portfolios (Edwards, 2004). Thus, institutions need to establish strategies that would enable efficient loan recovery from clients before getting overdue.

Several studies have been conducted on factors for effective credit collection in MFIs; but, the level of significance of factors varies with studies. Some of the determinants are found to be significant while others not. At the same time, some determinants are significant to only set of MFIs. Empirical evidences from the findings by Kar \& Swain, (2014); Adongo and Stork, (2000); Nyamsogoro, (2010) and Zohair, (2013) reported that interest rates, loan sizes and loan duration influence financial sustainability and portfolio performance of microfinance institutions. This is contrary to the findings by Tundui and Tundui, (2013); Folefack \& Teguia, (2016); Onyeagocha, et al., (2012) and Shu-Teng, et al. (2015) which indicated that, the factors were positively associated to repayment problems and against quality loan portfolio performance. Despite of essential contributions made on previous empirical studies, much of past research suffers from mixed findings leading to inadequate conclusions. In addition, some past studies have dwelt on memberbased microfinance institutions while other studies focused on only one microfinance programme. Consequently, they have been inefficient in establishing the factors contributing to effective credit collection policy on portfolio at risk of microfinance institutions in Tanzania. This study is comprehensive in coverage and focused on non- 
member-based microfinance institutions. Therefore, it intends to fill that gap by providing further insight and information on the role of microfinance credit collection policy on portfolio risk management in Tanzania.

\section{Related Literature}

Microfinance institutions need to have credit collection strategies that would make clients attracted to find it easy to repay their loans without enforcement. Institutions that constantly compels its clients to service their debt reflects weak credit collection policy employed that ensure timely collection of funds from clients. Palladini and Golgberg, (2010) considers credit collection policy as guidelines that establish set of procedures used to collect accounts receivable getting overdue. It aims at maximizing rate of return from microfinance loan portfolio in order to increase firms' assets value. The rationale of establishing a set of policy is that, not all clients meet their obligations timely and without enforcement. There are clients who simply forget and the rest don't have tendency of paying their dues until persuaded to do so. Lending institutes that experience gradual repayment of loans from clients, increase bad debts of their loan portfolios. Therefore, credit collection efforts are directed at accelerating loan recovery from clients.

Microfinance management efforts for making sure strict collection procedures are adhered; helps to keep debtors alert and reduction of portfolio at risk (Warue, 2012). As such loan portfolio is the microfinance institutions most important asset, that needs to be managed conscientiously against default risk. Survival of any lending institution depends on successful loan portfolio performance which results into increasing rate of return on various loan investment products.

Previous studies indicate that, portfolio performance of microfinance institution is influenced by various factors. Existence of attractive and customer-oriented credit collection strategies contributes to sound financial performance in microfinance institutions. Emran et al., (2006) and Papias, \& Ganesan, (2009) in their study observed that, microfinance institutions that charges high interest rates are likely to affect quality of loan portfolio due to increasing default rates. Consequently, impact negatively on overall financial performance of MFls. However, studies by Ayayi \& Sene, (2010) added that individual-based microfinance lenders charging higher interest rates are likely to be more profitable up to a certain level. Beyond which the profitability of microfinance institution tends to be worse due to an increase in rates of delinquency from their clients. As such, microfinance need to learn that, charging high interest rates beyond a certain threshold is said to be unfavorable for the MFIs financial sustainability. On the other hand, Hooman (2009) revealed that interest rate has the most significant effects on repayment performances. In the same vein, Ledgerwood (2013) suggested that microfinance institutions should be concerned about loan pricing of its products since it is an important aspect of loan product design. It is argued that a balance has to be reached between what clients can afford and what the lending organization needs to earn, to cover all costs involved in lending for sustainable microfinance operation.

Swain and Varghese (2013); Nyamsogoro, (2010) and Kar, \& Swain, (2014) advised that, financial institutions should charge higher interest rates only to credit facilities 
identified to have higher probability of default. As such businesses with high risk of success should attract higher interest rates. However, microfinance institutions should note that by introducing higher interest rates to borrowers, that may contribute to loan defaults and hence impact on loan portfolio. Mckernan (2002) shared the same view with Swain and Varghese that the high interest rates charged by most microfinance institutions on credit facilities significantly contribute to loan default. It was further argued that even if microfinance institutions may have effective appraisal and assessment strategies of their loan applicants. Increased interest rates charged to borrowers may lead to default payment and high rate of portfolio at risk of the microfinance institutions. At the other hand, a study by (Tundui \& Tundui, 2013) showed that interest rates charged to microfinance borrowers did not affect repayment performance of microfinance institutions. Hence, this study needs to determine the influence of interest rates on portfolio performance of microfinance institutions in Tanzania.

Moreover, Lidgerwood (2009) argued that, loan duration as designed by microfinance institution can greatly affect borrowers' repayment schedule, financing costs to the client and the extent of loan use by respective clients. Roslan and MohdZaini (2009); Godquin, (2004) added that, microfinance borrower who prefers longer period to complete loan repayment indicates commitment to repay the loan. That may contribute to improved financial performance and reduced risk of gross loan portfolio. These findings were in line with Onyeagocha, et al., (2012) \& Shu-Teng, et al., (2015) who pointed out that, increase of loan duration to borrowers negatively associated to institutional financial performance. Therefore, lending institutes need to devise various institutional mechanisms intended to reduce the risk of loan default for sustainable microfinance portfolio growth.

In addition, grace period to borrowers in microfinance institutions is said to influence repayment behavior of the borrowers. According to Barboni (2012), grace period as a technique of encouraging borrowers' regular loan repayment and improve microfinance collection process is practiced in two scenarios. Firstly, involves a situation where respective microfinance institution provides a borrower specific number of days before start of making regular loan repayment until completion of his loan amount. As such, there is no penalty for late payment after the given days expiry. The second technique of grace period involves the situation where a microfinance institution provides a borrower with a period of time where an interest rate is not charged on new loan offered. Abreham (2002) added that, provision of grace period to microfinance borrowers influence positively repayment performance and reduction of risk embedded in the microfinance loan portfolio. Similarly, microfinance institutions which provide a grace-period to their clients are said to enhance borrowers' entrepreneurship capability and attract borrowers into investment options of their business. Field et al., (2011) observed that, grace period increase microfinance institutions' financial performance thereby controlling for defaults rates to borrowers. These findings were in line with Pande et al., (2010) who found that microfinance borrowers who were offered grace period were encouraged to invest more in their business and were capable to finance their loan more regularly than clients without a grace period. 
According to Shariff (2013) microfinance loan size offered to borrower influenced repayment performance of microfinance institution. The loan sizes to borrowers can be designed into small, medium or big loan sizes. Most microfinance institutions design small and medium loan products to carter demands for low-income and poor household customers. Efficient loan size that fit capability of borrowers to repay reduces portfolio at risk of the gross loan portfolios Crabb \& Keller, (2006); Pischke (1991). On the other hand, Nyamsogoro (2010) observed that, profitability of microfinance institution lending business is associated with larger average loan sizes offered to their clients. However, Cull et al., (2007) argued that, microfinance institutions that provide smaller loans do accumulate higher profits in transacting with their clients. It is also an indication that, such small loan products are demanded by their clients. At the other hand, Feroze, et al., (2011); Berhanu, (2005), had contradictory observation who argued that, loan size of microfinance institutions does not influence microfinance financial performance.

The aim of this study was therefore to test how credit collection policy influence portfolio at risk of microfinance institutions. The hypothesis tested in this relationship are stated below: -

H1. 1: There is no significant relationship between microfinance institution interest rates charged and portfolio microfinance performance.

H1. 2: There is no significant relationship between microfinance institutions loan size offered and portfolio microfinance performance.

H1. 3: There is no significant relationship between microfinance institutions grace period of loans and portfolio microfinance performance.

H1. 4: There is no significant relationship between microfinance institutions loan duration and portfolio microfinance performance.

\section{Research Methods}

This study was a cross-sectional research design which used a large number of subjects that were not geographically bound. The use of a cross sectional design enabled undertaking of both quantitative and qualitative data. A comprehensive sampling frame of non-member-based microfinance institutions was generated by combining data set from the Bank of Tanzania (Microfinance section) (2010); the Ministry of Industry and Trade via the licensing department (2014); Tanzania Association of Microfinance Institution (TAMFI) (2015) and the SELF scheme (2015). The database provided information regarding the registration, operation and their outreach services. A total of 219 microfinance institutions of non-member-based microfinance institutions in Kinondoni, llala and Temeke districts in Dar es Salaam region, Morogoro urban district in Morogoro region and Dodoma urban district in Dodoma region were involved. Both primary and secondary data were collected.

\subsection{Model Specification}

The study employed multiple linear regression model as analytical model technique. The multiple regression examined the relationship between a single outcome measure and several predictor variables. The dependent variables in this study was 
portfolio at risk of MFIs. On the other hand, independent variables involved in this study were: - interest rates, grace period of loans, loan sizes and loan duration. The analytical model used for credit collection policy on portfolio at risk of microfinance institutions is shown as follows: -

The dependent variable was measured as;

Portfolio at risk (PAR) 90 days =

Outstanding principal balance of all loans past due more than 90 days

\section{Outstanding principal balance of all loans}

The linear regression model was of the following form:

$Y=\beta_{o}+\beta_{1} X_{1}+\beta_{2} X_{2}+\beta_{3} X_{3}+\beta_{4} X_{4}+\varepsilon$

Where: $Y=$ Predicted dependent variable (Portfolio at risk),

$\beta_{o}=$ Constant,

$\beta_{1}-\beta_{6}=$ regression coefficients,

$X_{1}-X_{4}=$ Value of the predictor variables -interest rates, grace period of loans, loan sizes and loan duration.

$\varepsilon=$ Error term

\subsection{Control variables}

This study has considered four control variables in analyzing the relationship between the hypothesized independent and dependent variables. The purpose was to minimize the contribution of the variables of interest after controlling for the other re-known factors. The control variables were MFls age, MFls size, Owner/manager education qualifications and Owner/manager experiences.

\section{Results and Discussion}

\subsection{Descriptive statistics of dependent, independent and control variables in sampled MFIs}

Table 1 presents the mean portfolio at risk of the surveyed microfinance institutions 8.9898 percent. The minimum average portfolio at risk was reported 3.67 and maximum was 21.00 percent. These results suggest that, on average microfinance institutions differ from one institution to another in loan portfolio management. This could be due to varying credit risk management strategies applied by respective microfinance institutions. The Table also shows variable average loan duration of MFI with a mean value of 245.242 days. The minimum and maximum loan duration are 90.0 and 1080.0 days respectively. This distribution indicates that borrowers in studied microfinance institutions takes about nine months to complete their loan installments. This further imply that, clients are in favor of loan products of less than one year. This helps the firms to actively manage their loan portfolios through effective monitoring and reduce problem loans.

The interest rates variable in the table indicates a minimum and maximum of 15.00 and 45.50 percent. In addition, the mean interest rates charged by microfinance institutions 
during the study period was 26.39 percent. The dispersion of the interest rates is 7.61423 percent. The results suggest that across the study areas, microfinance institutions charge high interest rates to their clients. There is possibility for microfinance borrowers to fail to carry the loan to maturity, leading to increased portfolio at risk of the lending institutes in the study areas. Furthermore, Table 1 below displays variable grace period of loans of microfinance institutions with a mean of 3.1553 days. The study again shows a minimum of 0.00 days and maximum of 30.00 days. The variation in the provision of grace period during the period of study was 6.4852 days. This implies that few microfinance institutions in study areas provides grace period of loans to their clients. This follows observed small mean value of the variable and the fact that, the study records zero minimum days from the microfinance institutions under study. The variable loan size exhibits a minimum and maximum of 250,000 Ths and $10,000,000$ Tsh respectively. Furthermore, the table also reports a mean loan size of $3,041,108.3$ Ths during the period under study. It also indicates a variation of 2,719,066.8 Tsh across microfinance institutions in study areas. The distribution generally denotes that, MFIs provides loan sizes that serves wide range of client needs. The mean loan size observed indicates further that, clients may access such loans to cater their business. That encourages efficient repayments and sustainable portfolio performance.

Moreover, descriptive statistics in Table 1 below, presents MFls age to have a mean value of 6.28 years. The study again shows a minimum and maximum MFIs age reported 3.00 and 15.00 years respectively. The age distribution indicates that, MFls involved in the survey had ample experience in microfinance operation and therefore suitable for the nature of this study. The Owner/manager experiences falls within a range of 2.00 years (minimum) and 18.00 years (maximum). The mean experience of MFI managers across the study areas was 6.00 years. The dispersion of owner/manager experiences is 3.29 years. These statistics implies that microfinance manager have reliable experience to lead the firm into sustainable business operation for achieving its social and financial objectives. Furthermore, the variable MFI sizes has recorded a mean of Tsh $276,014,051.74$. It also reveals minimum and maximum total assets of MFls to be Tsh $70,000,000.00$ and Tsh $615,000,000.00$ respectively. The variation in the amount of assets among microfinance institutions during the period of study was Tsh 184,098,247.16. The mean total assets of MFIs imply that, selected MFIs in this study are well rooted financially to provide credit services to the needy clients sustainably.

Table 1: Distribution of dependent, independent and control variables in sampled MFIs

\begin{tabular}{lccccc} 
Variables & Mean & Std. Dev & Min & Max & N \\
\hline $\begin{array}{l}\text { Dependent variable } \\
\text { Portfolio at risk (PaR 90) }\end{array}$ & 8.9898 & 2.98651 & 3.67 & 21 & 219 \\
$\%$ & & & & \\
Independent variables & 245.242 & 185.41061 & 90.00 & 1080.00 & 219 \\
Loan duration & 26.3904 & 7.61423 & 15.00 & 45.50 & 219 \\
Interest rates charged & 3.1553 & 6.48524 & 0.00 & 30.00 & 219 \\
Grace period of loans & 3041108.3 & 2719066.8 & 250000 & 10000000.00 & 219 \\
Loan size & & & & & \\
Control Variables & & & &
\end{tabular}




\begin{tabular}{lccccc} 
MFIs age & 6.28 & 2.189 & 3 & 15 & 219 \\
MFIs size (TAS) & 276014051.7 & 184098247.2 & 70000000 & 615000000 & 219 \\
Manager experiences & 6 & 3.294 & 2 & 18 & 219 \\
\hline
\end{tabular}

\subsection{Distribution of education level of Owner-managers in sampled MFIs}

The descriptive statistics in Table 2 below presents education qualification of Owner-managers of MFIs for the period. It shows that $23(10.5 \%)$ of microfinance institutions had managers with secondary level of education. Moreover, $101(46.1 \%)$ of managers among studied MFIs had post-secondary non-university education. On the other hand, $95(43.4 \%)$ of MFIs were managed by University graduates. The distribution suggests that most MFIs are managed by CEO with Post-secondary non-university education, followed University graduates. This further imply that, prevailing threats to portfolio performance of MFIs may be associated with chief executive officers' inability to effectively manage their MFls. Resulting to unsustainable financial performance and inadequate outreach to low-income clients.

\section{Table 2: Distribution of owner-managers' education qualification in sampled MFIs}

\begin{tabular}{lcc}
\hline \multicolumn{1}{c}{$\begin{array}{c}\text { Education level of Owner- } \\
\text { managers }\end{array}$} & \multicolumn{2}{c}{ Microfinance institutions } \\
\hline & Number & $\%$ \\
Secondary education & 23 & 10.5 \\
Post-secondary non-University & 101 & 46.1 \\
University & 95 & 43.4 \\
Total & 219 & 100.0 \\
\hline
\end{tabular}

\subsection{Correlations Analysis}

Table 3 below provides correlation matrix of the variables related to credit collection policy on portfolio at risk of microfinance institutions. The Pearson correlation results presented, indicates variable grace period of loans and loan size are negatively and significantly related to portfolio at risk of MFIs. In addition, variable interest rate is significant and positively related to portfolio at risk. The variable loan duration denotes insignificant relationship to dependent variable. On the other hand, the correlation table aids to verify for the collinearity between variables employed in a study. The 'rule of thumb' considers the existence of collinearity between predictor variables at a correlation value of 0.5 and above. Basing on this observation, the correlation analysis presented confirms to have no multicollinearity problems that exist between the variables in this study (Hair, 2010). 
Table 3: Correlation matrix of credit collection policy variables on PAR $(n=219)$

\begin{tabular}{|c|c|c|c|c|c|c|c|c|c|c|}
\hline Variables & 1 & 2 & 3 & 4 & 5 & 6 & 7 & 8 & 9 & 10 \\
\hline 1.Portfolio at risk & 1 & & & & & & & & & \\
\hline 2.Loan duration & -.090 & 1 & & & & & & & & \\
\hline 3.Interest rates & $.168^{*}$ & .056 & 1 & & & & & & & \\
\hline 4.Grace period & $-.140^{*}$ & .082 & .033 & 1 & & & & & & \\
\hline 5.Loan size & $-.171^{*}$ & .115 & -.058 & -.078 & 1 & & & & & \\
\hline 6.Manager exper & .088 & .023 & .045 & -.007 & -.015 & 1 & & & & \\
\hline 7.MFI age & -.063 & .012 & -.046 & -.080 & -.036 & .026 & 1 & & & \\
\hline 8.MFIs size & $.157^{*}$ & -.001 & .013 & -.043 & .012 & .048 & $-.133^{*}$ & 1 & & \\
\hline 9.Manager sec edtn & -.019 & .085 & -.096 & .040 & -.003 & $\begin{array}{r}.024 \\
-\end{array}$ & -.033 & $\begin{array}{r}.073 \\
-\end{array}$ & 1 & \\
\hline 10.Manager univ & .021 & $.137^{*}$ & .087 & -.068 & .106 & .090 & .127 & .077 & $-.246^{* *}$ & 1 \\
\hline
\end{tabular}

\subsection{Econometric Results}

This study aimed to determine the effect of credit collection policy on portfolio at risk of microfinance institutions in Tanzania. The multiple linear regression model was used in order to examine the combined effect of credit management practices on portfolio at risk. The level of significance ( $p$-values) was used to test the influence of each variable on portfolio at risk of microfinance institutions. An overall model fit was used to test the combined effect of all variables on the portfolio at risk of microfinance institutions. The overall model was significant at $F(9,209)=16.275 ; p=.002<0.05$. This means that, in general the concepts selected for this study did indeed explain a significant proportion of the variance in portfolio at risk of microfinance institution. Similarly, the study found that the estimated result of multiple regression analysis is also at a quite satisfactory level. The adjusted $R^{2}$ is 0.384 and observed $R^{2}$ value is 0.412 , respectively. This means that independent variables can explain about $41.2 \%$ of the portfolio at risk of microfinance institution. 
Table 4: Model results for credit collection policy variables on portfolio at risk of MFIs

\begin{tabular}{lcccc}
\multicolumn{1}{c}{ Variables } & Coefficients & Standard & T Value & P Value \\
\hline (Constant) & 5.254 & 7.836 & .670 & .503 \\
Log loan duration & -.974 & .858 & -1.135 & .258 \\
Interest rates & .061 & .026 & 2.350 & .020 \\
Grace period & -.068 & .030 & -2.239 & .026 \\
Log loan size & -1.487 & .570 & -2.611 & .010 \\
Manager experience & .072 & .059 & 1.209 & .228 \\
MFI age & -.086 & .091 & -.948 & .344 \\
Log MFI size & 1.661 & .775 & 2.143 & .033 \\
Manager sec education & .069 & .438 & .158 & .874 \\
Manager univ education & .504 & .641 & .786 & .433 \\
\hline R- Square 0.412; Adjusted R- Square 0.384; F- Statistic 16.275 & & \\
Prob. (F-stat) .002; Number of obs $219 ;$ Significant at $5 \%$ & & \\
\hline
\end{tabular}

PAR 90 days $=\beta_{0}-\beta_{1}(L O D)+\beta_{2}(I N T R)-\beta_{3}(G R P)-\beta_{4}(L S)+\beta_{5}$ Controls $+\varepsilon \ldots \ldots \ldots \ldots$.

Where:

$P A R=$ Portfolio at risk more than 90 days of MFIs

$L D=$ Loan duration, INTR = Interest rates, GRP = Grace period of loans, $L S=$ Loan size

Controls = control variables (MFI size, MFI age, Manager experience and manager education.

From Table 4 above, the variable interest rate was positively related and statistically significant at level of $5 \%(p=0.020)$. As such it contradicts the hypothesis that no relationship exists between microfinance institutions interest rates charged and portfolio performance. This means that, interest rates charged by MFIs is a determinant of portfolio at risk of microfinance institution. That is any unit increase of the rate of interest charged to microfinance borrowers results in increased portfolio at risk of the lending institution by 0.061 . The cost of the loan is likely to be not manageable by the borrowers leading to higher default rate and increase risk of loan portfolio of microfinance institution. In order for the microfinance institutions experience lower portfolio at risk. They have to charge low interest rates to their clients to enable manage regular loan repayments. These findings are in line with Wenner et al. (2007; Swain and Varghese (2013) and Papias \& Ganesan (2009) who shared that, high interest rates charged by most microfinance institutions on credit facilities contributed to loan default and low-quality portfolio performance of the company. Despite of strong appraisal and assessment strategies, high interest rates to borrowers results to default payments and high portfolio at risk of the MFIs. In addition, Mwangi (2016) added that, when lending rates rise, financial institutions attract its borrowers to invest into riskier projects for higher return on investment. In so doing, if such 
projects are going to fail, even the creditworthy borrowers are likely to shy off from borrowing. Ultimately, portfolio at risk of the microfinance institution rises which threatens long term operation of the company.

The variable loan size in the regression table above is negatively related and statistically significant at level of $5 \%(p=0.01)$. These findings imply that, if other variables are held constant, any unit increase of loan size to microfinance borrowers result in decrease risk of portfolio of microfinance institution by 1.487 . This further means that, microfinance institutions which provide reasonably big loan sizes to their borrowers, makes them more committed to their respective lending institutes. In addition, enables widen their investments and become negatively associated to repayment problems. Pische (1991); Crabb \& Keller (2006) and Adongo and Stork (2006) argued that, efficient loan size that fits capability of the borrower to repay stimulate client's enterprise performance. Portfolio at risk of microfinance institution is reduced if borrowers appreciate for the loan amount offered and honor their obligation of repayments. That, improves portfolio at risk and strengthen financial performance of the microfinance institution. On the other hand, microfinance institutions that provides bigger loan size to their clients implies that, one has proven experience in managing his business and proven committed in servicing given loan effectively.

Moreover, the findings of the variable grace period records negatively related and statistically significant at level of $5 \%(p=0.026)$. This means the variable is determinant of portfolio at risk of microfinance institutions. The findings further imply that a unit increase of grace period of loans leads to 0.068-unit reduction in loan portfolio at risk of microfinance institutions. The findings are against the hypothesis which stipulated that grace period is not related to portfolio performance of microfinance institutions. In this regard, provision of grace period to borrowers makes them utilize funds effectively into planned investment projects. Abreham (2002) added that, the provision of grace period to microfinance borrowers influence positively repayment performance and therefore reduction of risk embedded in the microfinance loan portfolio. In addition, Ngahu \& Wagoki (2014) added that, microfinance institutions which provides a grace-period to their clients enhance borrowers' entrepreneurship capability. More importantly, enable them reorganize accordingly to undertake their obligation of regular loan repayments.

\section{Conclusion and Recommendations}

This paper has presented the results of a study on the effects of credit collection policy on portfolio at risk of microfinance institutions in Tanzania. The study used a sample from three regions namely Dar es Salaam, Morogoro and Dodoma. Using multiple linear regression model analysis, results revealed that, loan size to borrowers, grace period of loans and interest rates charged to borrowers determines portfolio at risk of microfinance institutions. These findings further show that, loan size to borrowers and grace period of loans decreases portfolio at risk of microfinance institutions. This means that, high loan repayment from microfinance borrowers are associated with grace period and large loan sizes. Moreover, results show that, the variable interest rates charged to borrowers is evidenced to increase portfolio at risk of the microfinance institutions. Therefore, in the light 
of these findings, it is recommended that microfinance institutions need to reconsider the rate of interest charged to their clients. This would enable borrowers manage repayments and ensure sustainable portfolio of microfinance institution. Similarly, it is recommended that borrowers be given sufficient grace period to enable manage cost of loan offered. Also, microfinance institutions need to design loan products that suit customers to enable carry the loan to maturity and enhance quality of microfinance loan portfolio.

\section{Reference:}

Abreham G. (2002), Loan repayment and its Determinants in Small-Scale Enterprises Financing in Ethiopia: Case of private borrowers Around Zeway Area, M. Sc. Thesis, Addis Ababa University.

Adongo, J., Stork, C (2006) Factors Influencing the Financial Sustainability of Selected Microfinance Institutions in Namibia. The Namibian Economic Policy Research Unit (NEPRU). Research Report No. 39.

Ayayi, A.G., Sene, M. (2010), What drives microfinance institution's financial sustainability, The Journal of Developing Areas, Vol. 44 No. 1, pp. 303-324.

Barboni, G. (2012); Who does the grace-period really grace? Repayment flexibility in microfinance contracts! JEL

Berhanu A. (2005) Determinants of formal source of credit loan repayment performance of smallholder farmers: the case of north western Ethiopia, North Gondar, M.Sc. Thesis, Alemaya Univeristy, Ethiopia.

BOT, (2010), Risk Management Guidelines for Banks and Financial Institutions, Directorate of Banking Supervision, Bank of Tanzania, Dar es Salaam

Brown, K., Moles, P (2011) Credit Risk Management, Edinburgh Business School Heriot-Watt University, Edinburgh

Colquitt, J (2007), CREDIT RISK MANAGEMENT Third Edition; How to Avoid Lending Disasters and Maximize Earnings, McGraw-Hill, New York

Cull. R., Asli Demirguç-Kunt, Morduch. J. (2007). Financial Performance and Outreach: AGlobal Analysis of Leading Microbanks. The Economic Journal, 117, F107-F133.

Crabb, P.R., Keller, T. (2006). A Test of Portfolio Risk in Microfinance Institutions, Faith and Economics, pp 25-29

Edwards, B (2004), Credit Management Handbook, Fifth Edition, Gower Publishing Limited Gower House Croft Road Aldershot Hants GU11 3HR England.

Emran, M. S., at el., (2006) Microfinance and Missing Markets, Working paper, Department of Economics, Columbia University, New York.

Feroze, S.M, Chauhan, A.K., Malhotra, R. \& Kadian, K.S, (2011), Factors Influencing Group Repayment Performance in Haryana: Application of Tobit Model, Agricultural Economics Research Review Vol. 24, pp 57-65

Field, E. at el., (2011) Debt Structure, Entrepreneurship and Risk: Evidence from Microfinance, working paper,

Folefack, A.J., Teguia, J.S. (2016), Factors Influencing Loan Repayment by Credit Beneficiaries of Microfinance Institutions in The Far North Region, Cameroon, RJOAS, Vol. 3 No. 51

Godquin, M., (2004) Microfinance repayment performance in Bangladesh: How to improve the allocation of loans by MFIs. World Development 32, 1909-1926.

Hair, J. F. 2010. Multivariate data analysis: a global perspective, Upper Saddle River, N.J., Pearson.

Hooman (2009), Factors affecting loan repayment performance of farmers in Khorasan-Razavi province of Iran; University of Humberg, Iran 
Kar, A., Swain, R.B. (2014), Interest Rates and Financial Performance of Microfinance Institutions: Recent, European Journal of Development Research, Global Evidence,

Ledgerwood, J. (1999) Microfinance Handbook: An Institutional and Financial Perspective. The World Bank: Washington, D.C.

Ledgerwood, J, at el., (2013) The New Microfinance Handbook; A Financial Market System Perspective; World Bank, Washington DC.

Mix Microfinance World; (2010), Sub-Saharan Africa Microfinance Analysis and Bench marking Report. A report from Microfinance Information Exchange (Mix) and Consultative Group to Assist the poor (CGAP).

Mckernan, M. (2002). The impact of microcredit programs on self-employment profits: do non-credit program aspects matter? The Review of Economics and Statistics.

Mwangi, N (2016); The Effect of Interest Rates on Microfinance Institutions' Products in Kenya; A Case Study of Kenya Women's Finance Trust in Nairobi County, Chandaria School of Business; United States International University - Africa

Nyamsogoro, G.D (2010), Financial Sustainability of Rural Microfinance Institutions (MFIs) in Tanzania; A thesis submitted in partial fulfilment of the requirements of the University of Greenwich for the Degree of Doctor of Philosophy

Ngahu S.T., Wagoki A.J. (2014). Effect of Group Lending on Management of Loan Default Rates among Microfinance Institutions in Nakuru Town, Kenya, International Journal of science and Research (IJSR)

Onyeagocha, S. U. O., Chidebelu, S. A. N. D., Okorji, E. C., Ukoha, A., Osuji, M. N., Korie O. C. (2012) Determinants of Loan Repayment of Microfinance Institutions in Southeast States of Nigeria, International Journal of Social Science and Humanities, Vol.1 No.1

Pande, P.R at el., (2010) Impact of a grace period in microfinance loan contracts, Centre for Micro Finance; Egmore, Chennai, India

Papias M. M., Ganesan P. (2009) Repayment behavior in credit and savings cooperative societies Empirical and theoretical evidence from rural Rwanda. International Journal of Social Economics, Vol. 36 (5), pp 608-625.

Palladini, Golgberg, (2010) Managing risk and creating value with microfinance, the World Bank, Washington, D.C

Pischke, J.D. (1991), Finance at the Frontier: Debt Capacity and The Role of Credit in the Private Economy, EDI Development Studies, The World Bank, Washington D.C.

Roslan, H.A., MohdZaini, A (2009), Determinants of Microcredit Repayment in Malaysia: The Case of Agrobank; Humanity \& Social Sciences Journal 4 (1), pp 45 - 52

Shariff, M.M (2013), Determinants of repayment performance in microfinance programs in Malaysia, Volume 11,

Shu-Teng, L., Zariyawati, M.A., Suraya-Hanim, M., Annuar, M.N (2015) Determinants of Microfinance Repayment Performance: Evidence from Small Medium Enterprises in Malaysia, International Journal of Economics and Finance; Vol. 7, No. 11

Schmittlen, M. (2010), Micro credit and the poorest of the poor, theory and evidence from Bolivia, Journal of microfinance Vol 2 No 1 pp 12.

Swain, R.B., Varghese, A, (2013) Delivery Mechanisms and impact of microfinance training in Indian self-help group, Journal of International Development

Tanzania Association of Microfinance Institutions (TAMFI), (2014) Members Directory, Uporoto Street, Dar Es Salaam. Tanzania.

Tundui, C and Tundui, H, (2013), Microcredit, Micro Enterprising and Repayment Myth: The Case of Micro and Small Women Business Entrepreneurs in Tanzania, American Journal of Business and Management Vol. 2, No. 1 
Warue, B.N., (2012) Factors affecting loan delinquency in Microfinance in Kenya. International Journal of Management Sciences and Business Research. Vol.1 Issue 12.

Wenner, M., et al. (2007) Managing Credit Risk in Rural Financial Institutions in Latin America; InterAmerican Development Bank.

Zohair, M. (2013). Factors Affecting Repayment of Loans by Micro-borrowers in Tunisia: An Empirical Study. 